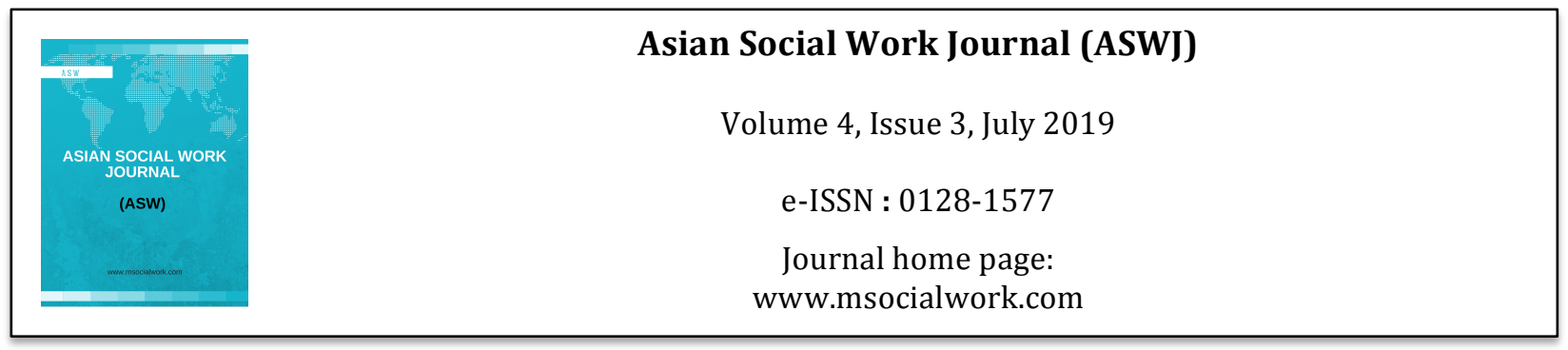

\title{
Implementation of Social Assistance for Persons with Intelletual Disabilities
}

\author{
Dedek Roslina ${ }^{1}$, Ety Rahayu ${ }^{1}$ \\ ${ }^{1}$ Department of Social Welfare, Faculty of Social and Political Sciences, Universitas Indonesia \\ Corrrespondence: Dedek Roslina (dedekroslina@gmail.com)
}

\begin{abstract}
Distance Service Program (DSP) is a community based rehabilitation program for persons with intellectual disabilities. This program has been running 11 years and is considered able to improve the wellbeing of persons with intellectual disabilityies and their families. In 2017, DSP implemented in West Bandung regency by rehabilitating 30 persons with intellectual disability. At the end of the program, beneficiaries receive cash aid to be managed as productive economic business capital. This article discusses the process by which the beneficiary families together with community cadres in managing the social assistance. The research method used is qualitative with descriptive research type. 13 selected informants represent program managers, program implementers, and program beneficiaries. The results of the field findings indicate that the beneficiary families of DSP 2017 have used the cash aid in accordance with the plan. Most of them are able to manage productive economic business and supplement family income by involving beneficiaries. The findings also reveal participatory economic empowerment by maximizing the potential of intellectual disabilities. However, there are also some types of endangered businesses consumed, dead fowls exposed to the virus, and businesses that take a long time to earn income for the family.
\end{abstract}

Key words: social assistance, productive economic business, intellectual disability

\section{Introduction}

Intellectual disability is one type of disability characterized by obstacles in cognitive function and adaptive behavior before the age of 18 years. Zastrow (2004) and Santrock (2000) suggest that intellectual disability is the largest subset of developmental disabilities. However, Law No. 8 of 2016 mentions intellectual disability as one of four different disabilities (physical, mental, sensory, and intellectual), separating developmental disabilities such as Autism and Attention Deficit Hyperactivity Disorder (ADHD) into mental disability, or cerebral palsy into physical disability. The differentiation of these types of disabilities leads to confusion in the classification of intellectual disabilities. Irwanto, et al. (2010) also argues that disability surveys conducted by the Government of Indonesia are unable to properly represent the prevalence of disability in the mental and emotional categories.

Data of intellectual disabilities in Indonesia used by the Ministry of Social Affairs refers to the results of the Intercensal Population Survey (SUPAS) of Central Bureau of Statistics of 2015 with the categorization of difficulty / disturbance in terms of recall or concentrate. The results of SUPAS 2015 show that the number of Indonesian population aged 10 years and over who have difficulty remembering and concentrating, men and women, both in urban and rural areas, as many as 5.852.478 persons. From the data is also known that the West Java Province has the second rank of the largest population with the most concentration and memory disorder, as many as 996.122 persons (after East 
Java Province). This data has not been able to represent the condition of intellectual disabilities that can not be ascertained by observation only, but it is necessary to extract information about the abilities in daily activities, the ability to understand the lessons, including emotional disturbance and disruption in play or study. In addition, many persons with intellectual disabilities are hidden by the family because it is considered a disgrace and even a curse.

Developmental disorders by disabilities in intellectual function caused many obstacles in life. These barriers are particularly related to the lack of skills during the development period ie the limitations of cognitive, linguistic, motoric, and social abilities. The Ministry of Social Affairs of Indonesia (2009) mentioned that in general, persons with intellectual disability are more vulneBPle and have weak immune system due to congenital abnormalities, heart disorders, motor disorders, etc. Such limitations can cause obstacles in adaptive functioning and adjustment to the social environment, difficulties in carrying out daily life activities, learning difficulties, difficulty in relationships, and difficulty in acquiring skills and employment. Because of these barriers, persons with intellectual disabilities need help and support to develop their potential.

Over the last three decades, there has been a shift in the philosophical and sociological foundations affecting social rehabilitation practices for persons with disabilities in Indonesia from medical models to social models. This shift in approaches reflects that disability is no longer seen as a medical problem but a social problem that requires attention and mutual care, especially involving families and communities. Jewell (2010) emphasizes that social models are social constructions where one's limitations are not the cause of problems, but the environment fails to provide services and access to the needs of persons with disabilities. Community Based Rehabilitation is an intervention strategy developed by WHO and other international organizations to meet the needs of persons with disabilities in developing countries. This strategy aims to improve the quality of life of persons with disabilities and theycarerswith a focus on basic needs and ensure the creation of an environment of inclusion and participation of local resources (Lemmi et al, 2015).

Government efforts to address intellectual disability issues include social rehabilitation through institutional based and outreach program / non-institutional systems such as family / community based social rehabilitation. The strategy adopted by Rehabilitation Center for Persons with Intellectual Disabilities Ciungwanara Bogor in order to organize non-institutional and family-based social rehabilitation (home care) is to create an outreach service program called Distance Services Program (DSP). This program has been implemented since 2007 to expand the network of social welfare effort for persons with intellectual disabilities, empower parents / families so they can participate in providing social rehabilitation services to persons with intellectual disabilities, and accommodate the needs of community who need services and social rehabilitation for persons with intellectual disability which is implemented in their environment.

DSP 2017 implemented in District Cililin and Lembang, West Bandung regency by rehabilitating as many as 30 persons with intellectual disabilities. West Java Province is an area of Ciungwanara PSBG which is a region with a large population of persons with intellectual disabilities. The target of the DSP is the poor families with children with intellectual disabilites. In addition to trying to provide social rehabilitation services, DSP also seeks to reduce poverty by providing productive social assistance for beneficiary families. There have been many studies discussing the linkage between disability and poverty. Lemmi, et al (2015) noted that there are more than 1 billion persons with disabilities in the world and $80 \%$ of them live in developing countries. They are threatened to live in poverty because of lack of access to education, health, employment, and other social aspects. If poverty is considered in the context of the SDGs, then disability issues should be addressed. SDGs will not be achieved if disability issues are not taken into account. Elwan (1999) in Palmer (2011) also points out that disability and poverty are interconnected and create consequences for each other. In the range of intellectual disabilities, for example, poor families who are unable to meet basic needs are at risk of delivering malnourished children who may experience intellectual disability. Children from poor families who are not stimulated or abandoned have the potential to experience intellectual disability. In contrast, families with intellectually disabled children need a big fee for the care and treatment of their child that will last a lifetime. So disability can cause poverty. 
There are several studies that attempt to explain the process, evaluation of effectiveness, and review of social assistance programs for the poor in developing countries. Those anti-poverty programs show considerable innovation and diversity that shaped by domestic factors. Barrientos (2013) has conducted social assistance research in developing countries in Latin America, Asia, and Africa. He categorizes the type of social assistance in Indonesia into two types, such as the Direct Cash Assistance Program as a pure income transfer for general subsidies to poor household, Social Safety Net Program (JPS) and Hopeful Family Program (PKH) as income transfer plus for human development . Asmaroini (2012) has examined the effectiveness of social assistance for idiots in Ponorogo Regency. Social assistance is provided by the government, the private sector, and the community that can generally mitigate family burden. However, assistance is provided directly without the process of assessing program beneficiaries needs. These studies also do not analyze the type of social assistance provided to manage the family's productive economic enterprise. This study aims to determine the implementation of social assistance and the effectiveness of social assistance to the family's economy in DSP 2017 in West Bandung regency, which not only provides family opportunities for entrepreneurship with the participation of persons with intellectual disabilities and community cadres.

\section{Methodology}

This research uses qualitative approach with descriptive type. The selection of qualitative approach is to obtain information and data deeply on the process of DSP social assistance management in West Bandung regency. As confirmed by Ragin (1994) in Neuman (2014): "Qualitative methods, by contrast, are best understood as data enhancers. When data is enhanced, it is possible to see more aspects of cases more clearly." Data collection techniques used were observations of accompanying activities, interviews with 13 informants, and documentation studies of various program reports. While data analysis techniques by using data reduction, data display / data presentation, and data verification / withdrawal of conclusions.

\section{Findings}

The provision of social assistance for recipients with a new cash transfer system is implemented in DSP 2017. In previous years the beneficiaries received stimulant assistance in the form of goods in accordance with the results of business type assessment. The cash transfer system is implemented in accordance with the mandate of the President of the Republic of Indonesia to ensure the recipient of the service receives a full grant. The Rehabilitation CenterCiungwanara plays role to ensure DSP aid funds in 2017 used as a productive economic business capital that will help the recipient family economy. The process of providing stimulant assistance involves local community cadres in both ofCililin and LembangDistrict as program assistants. They are able to establish good relationships with beneficiary families because they are part of community who know the local language, culture, and play an active role in various social activities involving the community. They are able to perform assistance tasks in DSP stimulant assistance by probing information needs and business potential that can run family of beneficiaries.

The provision of DSP stimulant assistance in 2017 includes the business assessment phase, proposal formulation and the Budget Plan (BP), the disbursement of funds at the bank, the capital expenditure, the preparation of expenditure reports, and business management monitoring.

\section{Assessment of business type}

After DSP2017 runs 6 months, Rehabilitation CenterCiungwanara began assigning DSPcommunity workers to conduct assessment of business needs of parents of beneficiaries. Every parent of DSP 2017 beneficiaries receive funding of $\mathrm{Rp} \mathrm{3,000,000} \mathrm{(or} \mathrm{\$ 230)} \mathrm{to} \mathrm{be} \mathrm{used} \mathrm{as} \mathrm{productive} \mathrm{economic} \mathrm{business.}$ The community workers assess the needs of the economic business of each parent of beneficiariesaccording to the program manager's direction, ie by consideration of the land, the competitor of the business around them, and the family's ability. For families who want poultry 
businesses to consider the availability of land for cages near their homes. For families planning to open a minishop should consider competitors around their residence. If a stall is found close to their residence, the community workers should direct the beneficiaries's family to distinguish the types of merchandise in the stalls to be run, such as rice stalls, grocery stalls, food stalls, etc. The assessment process should also consider their ability in entrepreneurship, such as their ability to trade, farming, baking, and other activities they normally run. Program managers insist that recipient families are not affected by the successful efforts of others / neighbors, but rather pay attention to self-ability. The experience and capabilities of the parents of the beneficiaries make it easier for them to manage DSP grants. Several beneficiary families were found to use funds to increase the capital they were running.

The community workers offers the best possible advice on the type of business the parents decide. One is the parent of the recipient who asks for a sheep but the community workers directs the parent to consider the choice of selling hawkers that have been run given the condition of parents who do not have a permanent job. Another consideration is the sheep business takes a long time, while selling hawk gives parents the opportunity to earn income for the family daily needs. If the aid of a stimulant is still bought for a sheep, it is probable that the sheep will be sold in the near future.

Among these types of businesses there are those who want to develop a business that has been run, some are starting a new business. Businesses that have been run for example goat and cow farming, vegetable stalls, snack business, and growing cactus. Parents who have never entrepreneurship are helped and motivated to determine the business they can run. All beneficiaries's parents work in the informal sector. Some of them work seasonally like farm laborers. Businesses that are run strived to help them still have income especially in difficult times.

The types of business that run by DSP 2017 beneficiary families can be seen in the following graph:

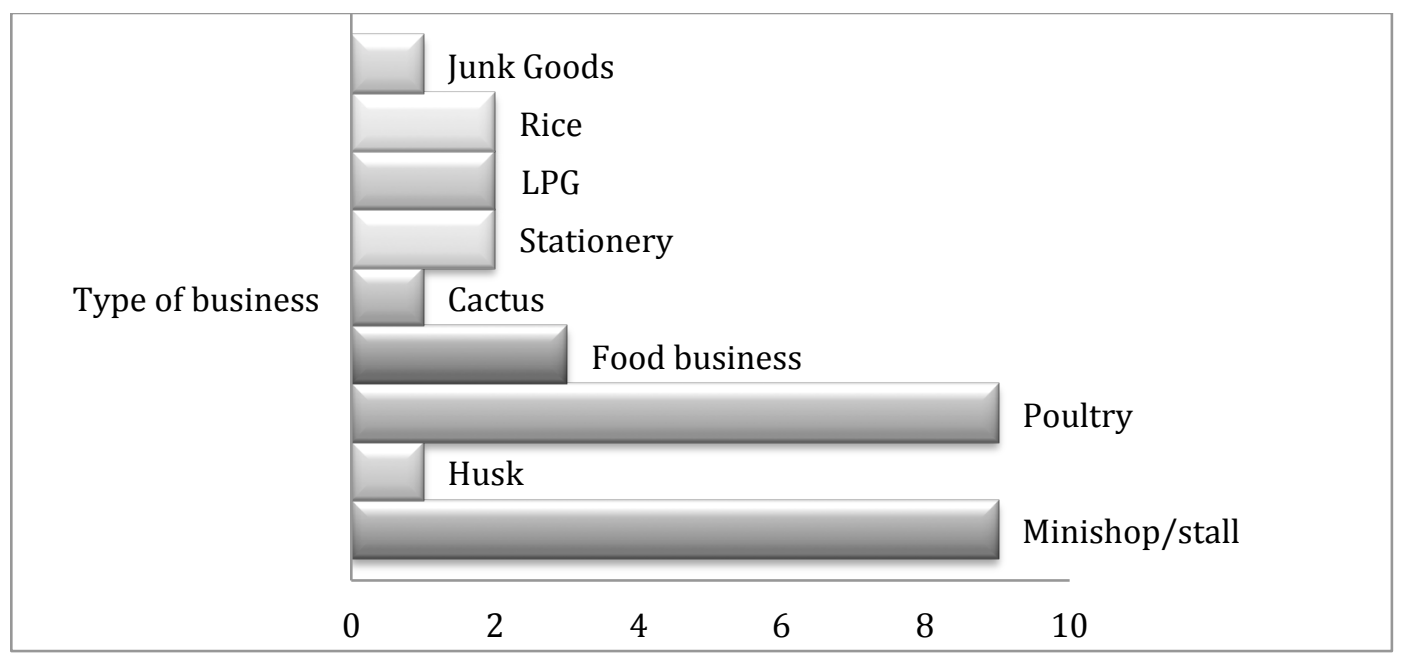

Figure 1 Recapitulation of type of business of DSP 2017 beneficiaries

\section{Preparation of Proposal and Budget Plan of Business (BP)}

After determining the type of business based on the assessment, the community workers is assigned to prepare the proposal and BP. The community workers help each other out a proposal. Some of them lacked computer skills so that the process of typing the proposal was carried out by one of the community workers. Subsequent proposals and BP submitted to Rehabilitation Center Ciungwanara for follow-up. The completion of the proposal consists of a photocopy of bank savings book (as instructed by the program manager to facilitate the disbursement of assistance), details of BP, as well as photocopy of family card and identity card of the beneficiaries's parents. Nine types of proposed community workers efforts are approved by the program manager to proceed to the disbursement stage of the aid. 


\section{Disbursement of stimulant aid at the banks}

After obtaining the information the aid has been sent, the parent and the community workers in each sub-district go to the bank together. In Lembang District, the disbursement process is controlled entirely by the Coordinator of community workers with the agreement of the parents. Lembang'scommunity workers accompanies parents to the bank, guide them for the signing of money withdrawals, and collects all grants to the Coordinator. Furthermore, the Coordinator of community workers will hand over the money to the community worker who handles the concerned beneficiaries on the day they will shop. The tight control mechanism of the stimulant aid is done by the Coordinator community workers to anticipate the inappropriate use of aid.

However, Coordinator of community workers did not carry out the same control mechanisms to the community workers in Cililin District due to long distances. Community workers in Cililin District developed their own aid disbursement mechanism whereby all parents of the recipients were collected at elementary inclusive school in Cililin to be briefed and went to the bank together. After the withdrawal process, the parents hold the money themselves and shop with a community workers.

\section{Stimulant aid spend}

In addition to differences in disbursement mechanisms, there are differences in spending mechanisms in both districts. The beneficiary parents in Lembang are not allowed to hold the money so that the community workers who makes the payment after the parents finished choosing the goods. There are also beneficiary parents who are just waiting for the goods delivered to their home. While in Cililin, parents hold their own money and shop alone with supervisory community workers. Because of holding their own money, parents are still trying to negotiate with a community workers not to spend all their money or buy needs outside the BP. However, the community workers in both districts have made sure the expenditure, the collection of the receipts, and the making of accountability reports are in accordance with the BP.

\section{Preparation of expenditure reports and goods handover reports}

The community workers of DSP 2017 prepare an expenditure report containing a memorandum on the purchase of stimulant assistance and a handover of the goods signed by the beneficiary parents. In the October 2017 on DSP Monitoring and Evaluation Activities, they report had reviewed by program managers. From the observation and documentation study found some shopping notes that are not in accordance with BP, wrong sum, and items that are not allowed such as freight and transportation costs.

\section{Monitoring entrepreneurial sustainability}

In each rehabilitation meeting with the beneficiaries, the community workers monitor the development of stimulant aid management. From the observation result can seen that the turnover of the business of parents has been seen even though it has only been running for 1 month, among others, LPG business has been sold in two weeks, the ornamental cactus business which has been exporting to California, US, stall business which start to get many customers, chips and snack which has increased production, etc. The business that takes a long time to rotate the capital is sheep and cow farming. However, program managers do not provide knowledge of bookkeeping and business management to community workers and the beneficiary parents. From the results of the interview it is known that DSP stimulant aid is a social assistance to improve the economy of beneficiary families without any consequences.

The provision of stimulant assistance is carried out in accordance with the policy of Rehabilitation CenterCiungwanara Bogor as the program manager. The program beneficiaries and their family are given stimulant assistance to help support the family economy and in an effort to hone the productive economics of beneficiaries (persons with intellectual disabilities). From the findings is known that the provision of stimulant assistance for the families of DSP 2017 beneficiaries is a form of social assistance which the program manager does not apply any sanctions in case of inappropriate 
management of stimulant assistance. Program managers only ensure the disbursement of aid with the cash transfer system runs correctly, grants are received by beneficiary families in accordance with existing budgets, spent according to BP, and managed to help the family economy and motivate beneficiaries to engage in family productive economic activities.

Social assistance with the cash transfer system spent in accordance with the needs and potential of beneficiary families can help them more productively. In addition, the management of stimulant assistance is also supervised bycommunity workers to keep the families manage the assistance as well as possible. The provision of stimulant aid is also able to involve the beneficiaries in their family's economic business activities where they meet to help parents wrap chips and snack, manage stalls, graze the goat, carry LPG, etc.

From the findings also known that there is an endangered economic effort consumed i.e stall/hawk selling. This happens to parents who can not turn on business capital or spend back stall's goods that have been sold. In addition, parents who do not have a steady income and face a difficult time because no job will consume stimulant items to meet daily needs. The results of the observation also shows that there are parents who failed to manage the poultry business because of a virus that is endemic at that time. From 60chickens and ducksremains 10 chickens in the span of 2 months. The parent who run this business admitted that this was the first time they started a poultry business. In addition to losses due to dead chickens, family health is also threatened because the poultry cage is placed in front of the door of theirhouse that interfere with air circulation and make anyone itching when visiting their home. As for goats and any poultry requires maintenance long enough to produce results so that parents with the poultry business has not gained profits. However, service recipients can be empowered to feeding these animals.

\section{Discussion}

Law No.11 Year 2009 on Social Welfare is a representation of government policy to follow up social problems in Indonesia. This law explains that in order to achieve social welfare for all Indonesians, social assistance / grants are allocated to the State / Local Budgets in Indonesia. The distribution of social assistance is regulated, among others, for social rehabilitation, social security, social empowerment, social protection, and poverty reduction.

Law No. 11 Year 2009 also states that social assistance is an effort directed to alleviate suffering, protect, and restore physical, mental, and social conditions (including psychosocial and economic conditions) and empower the potential for a person, family, group and / or communities that experience shocks and social vulnerabilities can live a reasonable life. The definition is in accordance with the provisions set forth in the Regulation of the Minister of Home Affairs of the Republic of Indonesia Number 32 Year 2011, paragraph 1 of Article 15 that the classification of social assistance includes: a) Consumptive social assistance expenditures; b) Productive social assistance spending; and c) Spending on social assistance provided to certain educational, health, and institutional institutions. The stimulant assistance of DSP 2017 is a form of productive social assistance which aims to provide business capital to the economically weak community. The aid is in the form of money that is handed over directly to the poor as business capital with the aim that they can continue to meet basic needs despite social risks such as social crisis, economic crisis, or disaster.

The distribution of social assistance with the cash transfer system in DSP 2017 is also carried out in accordance with the mandate of Presidential Regulation No. 63 of 2017 where the Rehabilitation CenterCiungwanara (working unit of the Ministry of Social Affairs) as a social donor channeled funds through the Distributorship Bank to the account on behalf of the Beneficiaries. Distribution of social assistance with cash transfer is expected to be done efficiently to be received on target, appropriate quantity, timely, appropriate quality, and proper administration. The recipients of DSP social assistance are the right target of assistance because they consist of intellectual disabilities from poor families. All beneficiaries ofDSP2017 have received the right amount of aid. However, DSP's social assistance differs from other non-cash social assistance (such as non-cash food aid or Family Hope Program from 
Ministry of Social Affairs of Indonesia), as this aid is only given once as a stimulant of productive economic activities towards the end of the program.

Referring to Daigneault (2014) that social assistance consists of 3 paradigms such as Entitlement paradigm, Workfare paradigm, and Activation paradigm. DSP stimulant assistance 2017 is a form of Activation paradigm where the state and society play an important role in realizing the welfare of persons with intellectual disability. The state intervenes on the provision of funds, the formulation of strategies and targeting, with the value of equality of opportunity and meritocracy. In this case the state also ensures the protection of beneficiary families against a greater range of risks than the ripple of poverty and their intellectual disability issues. On the other hand, this paradigm directs beneficiary families to be responsible for their own welfare through the management of productive economic enterprises.

The provision of social assistance is done through several stages such as business type assessment, proposal formulation and BP, fund disbursement in the bank, stimulant aid spending, to business continuity monitoring. The five stages of implementation are inseparable from the role of community workers as the main duty bearer ensuring that the program targets receive full assistance and manage the grants in accordance with the plan. In addition, they also pay attention to the aspect of beneficiary participation in the productive economic business that the family runs from the DSP social assistance. A Darragh (2017) study also reveals that one key to effective job matching for persons with intellectual disabilities is to pay attention to their abilities and skills, as well as support from their parents, families and surrounding systems. DSP 2017 beneficiaries can be empowered through poultry business, grocery, LPG, and snack foods (snack and chips) with family supervision. They are able to perform monotonous activities with diligence accompanied by the support of family members and community workers.

Productive economic business from the cash transfer assistance in DSP is also able to improve the family economy and answer the problem of poverty trap and lack of human capital in Activation paradigm. Persons with intellectual disabilities in Indonesia is difficult to work due to limited knowledge and skills. Productive economic activity from DSP stimulant assistance is able to provide informal business opportunities for persons with intellectual disabilities where they are involved in family business. In addition to having productive activities, persons with intellectual disability also become more confident and can socialize with the community (as a customer). On the other hand, the community can understand the conditions, problems, and potentials of intellectual disabilities. Persons with disabilities generally have various obstacles in economic activity, either due to being excluded in education or low self-esteem. According to Cobley (2012), there are three stages of economic empowerment for persons with disabilities such as vocational skills development, self-directed employment, and formal sector employment. DSP's productive economic business is a form of vocational skill development that provides access for persons with intellectual disabilities to improve vocational skills and broad the way for economic empowerment. The important factor of economic empowerment in Cobley (2012) is the acceptance of family members. Personswith intellectual disabilities who have been dependent on families for years also need respect and trust to be able to live independently. Through productive economic business,persons with intellectual disabilities are given the opportunity to engage in empowerment processes and demonstrate their best abilities.

The process of assessing the type of business provides an opportunity for the family to make decisions while the community workers only directs and advises. However, because the business capital is given only once, the consideration of business sustainability becomes important. In addition, the experience and security aspects are also important to consider. Family of beneficiaries who ran out of poultry due to the death of a virus was the impact of a less-than-deep assessment. They should be provided with education about family health care such as placing cages away from home. Inadequate poultry stimulant assistance is given to families who do not experience in poultry business. After all the chickens/ducks have died, they have nothing to support the family economy.

As a social model program, DSP seeks to fight for the rights of persons with intellectual disabilities by encouraging participation in the process of social rehabilitation as well as economic empowerment through productive social assistance. The program involves the central government as a major service 
provider and local government in ensuring program sustainability and realizing an inclusive environment. To improve the productivity and sustainability of family-run business, it is important to assist the methods of food processing, packaging, financial management, and bookkeeping. The role of community cadres and local government is needed to continue to assist families with intellectual disability children can remain economically empowered.

\section{Conclusion}

DSP stimulant assistance is a productive social assistance for the family of program beneficiaries to reduce the risk of social shock especially with the presence of persons with intellectual disability in the family. In general, the implementation of social assistance in productive economic activities targeted program in Cililin and Lembang District, West Bandung Regency has been going well according to the planning. Family-run economic activities (including beneficiaries) are able to meet basic needs and help families during difficult times for families with no fixed income. However, the effectiveness of social assistance in improving the family economy has not been experienced by all program targets due to inappropriate business type assessment and lack of family skills in managing the business.

\section{References}

AAIDD. (2010). Intellectual disability:Definition, classification, and systems of supports $\left(11^{\text {th }}\right.$ ed). Washington D.C: AAIDD.

Asmaroini, A.P.(2012). Efektifitas bantuan sosial bagi masyarakat kampung idiot di Desa Karangpatihan Kecamatan Balong Kabupaten Ponorogo. Available from http://library.um.ac.id/free-contents/printjournal.php/54413.html. (Accessed 14th May 2018)

Barrientos, Armando. (2013). Social assistance in developing countries. UK:Cambridge University Press.

Bollard, M. (2009).Intellectual disability and social inclusion.London: Churchill Livingstone Elsevier.

Daigneault, P., M., (2014).Three paradigms of social assistance. (Online) Available from http://journals.sagepub.com (Accessed $7^{\text {th }}$ May 2018)

Cobley, D.,S. (2012). Towards economic empowerment for disabled persons: Exploring the boundaries of social model of disability in Kenya and India.Ph.D Thesis. Available from http://etheses.bham.ac.uk/4050/ (Accessed $7^{\text {th }}$ May 2018)

A Darragh, A. (2017).Keys to effective job matching for individuals with intellectual disabilities.Abstact of $71^{\text {st }}$ Annual Meeting of the American Academy for Cerebral Palsy and Developmental Medicine (AACPDM), September 13-16,2017, Montreal, Quebec, Canada.

Irwanto, et.al. (2010). Analisis situasi penyandang disabilitas di Indonesia: Sebuah desk-review. Pusat Kajian Disabilitas Fakultas Ilmu Sosial dan Ilmu Politik Universitas Indonesia Depok.

Jewell, P. (2010). Disability ethics: A framework for practitioners, professionals and policy makers. Australia: Common Ground.

Kirst-Ashman, K.K. (2013). Social work \& social welfare: Critical thinking perspectives $\left(4^{\text {th }} e d\right)$. Brooks/Cole Cemgage Learning.

Neuman, W.L. (2014). Social research methods: Qualitative and quantitative approaches $\left(7^{\text {th }}\right.$ ed.). USA: Pearson Education,Inc.

Palmer, Michael. (2011). Disability and poverty: A conceptual review. Journal of Disability Policy Studies. Available from http://jdps.sagepub.com (Accessed $26^{\text {th }}$ March 2018)

Santrock, John W. (2000). Psychology (6 $\left.6^{\text {th }} e d\right)$. USA: McGraw Hill.

Ichsan, T. (2013).Anakkudown syndrome: Bungarampai. Depok:Insos Books.

Van Teijlingen, E.R. (2017). The medical and social model of childbirth.Kontakt XIX/2:8182.http://casopis-zsfju.zsf.jcu.cz/kontakt/administrace/clankyfile/20170619133230503336.pdf

Zastrow, C. (2004). Introduction to social work and social welfare ( $\left.8^{\text {th }} e d\right)$.Bellmont: Thomson. 